\title{
EVALUASI IMPLEMENTASI PENDIDIKAN KARAKTER DI SMK NEGERI 1 MARIORIWAWO KABUPATEN SOPPENG
}

Oleh:

\author{
BAHARUDDIN M. \\ PENELITIAN DAN EVALUASI PENDIDIKAN \\ UNIVERSITAS NEGERI MAKASSR
}

Email: abiyah_77@yahoo.co.id

\begin{abstract}
ABSTRAK
Penelitian ini bertujuan untuk mendapatkan deskripsi empirik sekaligus mengevaluasi pelaksanaan pendidikan karakter di SMK Negeri 1 Marioriwawo kabupaten Soppeng. Jenis penelitian ini adalah penelitian evaluasi melalui pendekatan kualitatif dengan menggunakan metode deskriptif analisis yang didukung oleh pendekatan kuantitatif. Analisis data pada penelitian ini menggunakan analisis data deskriptif dalam bentuk distribusi frekwensi dan persentase. Adapun nilai karakter secara keseluruhan dikategorikan mulai berkembang. Sedangkan nilai evaluasi implementasi pendidikan karakter berdasarkan masing-masing aspek yaitu: (1) aspek konteks berada pada kategori baik, (2) aspek input masih berada pada kategori agak baik, (3) aspek proses berada pada kategori baik, dan (4) aspek produk berada pada kategori baik.
\end{abstract}

\begin{abstract}
The study aimed at discovering the empirical description and evaluating the implementation of character education at SMKN 1 Marioriwawo in Soppeng. This study was an evaluation research with qualitative approach by employing descriptive analysis method supported by by quantitative approach. Data were analysed by using descriptive data analysis in aform of frequency distribution and percentage. The overall character value was categorized as started to develop; whereas the evaluation on the implementation of character education based on each of the aspect were (1) the context aspect was in good category, (2) the input aspect was in fairly good, (3) the process aspect was in good category, and (4) the product aspect was in good category.
\end{abstract}




\section{PENDAHULUAN}

\section{Latar Belakang Masalah}

Pendidikan merupakan pilar utama tegaknya suatu bangsa, melalui jalur pendidikan suatu bangsa melahirkan generasi-generasi yang handal dan unggul baik dalam ilmu pengetahuan (iptek) maupun iman dan taqwa (imtaq). Sebagaimana pendidikan nasional mempunyai visi terwujudnya sistem pendidikan sebagai pranata sosial yang kuat dan berwibawa untuk memberdayakan semua warga negara Indonesia berkembang menjadi manusia yang berkualitas sehingga mampu dan proaktif menjawab tantangan zaman yang selalu berubah. Chandler (dalam Patoni, 2012: 1) mengemukakan bahwa pendidikan diakui sebagai suatu hal yang vital baik bagi individu yang kapasitas intelek dan kreativitasnya menjadi meningkat, maupun bagi bangsa dimana mereka merupakan kekuatan dari sumbersumber manusia yang terlatih.

Senada dengan hal itu, Schwartz masih (dalam Patoni, 2012: 3) menjelaskan bahwa pendidikan karakter membantu para siswa mencapai sukses baik di sekolah maupun dalam kehidupan, pendidikan karakter membantu meningkatkan prilaku prososial dan menurunkan sikap dan prilaku negatif para siswa. Terlihat jelas bahwa pendidikan karakter memunculkan harapan dan optimisme khususnya bagi kehidupan persekolahan, tidak saja pada wilayah kognitif tapi juga wilayah psikomotor (Iskandar, 2013). Dengan pendidikan karakter, setidaknya ada tiga hal yang menjadi harapan yaitu: sukses dalam sekolah dan luar sekolah, meningkatkan perilaku yang baik dan menurunkan perilaku yang buruk. 
Realita dewasa ini menunjukkan bahwa dekadensi moral sudah sedemikian akut yakni, konflik sosial, meningkatnya kekerasan dan kenakalan oleh remaja seperti perilaku mengkonsumsi minuman keras, dan narkoba, tawuran antar pelajar, tindakan anarkis yang berujung pada penganiayaan terhadap sesama. Berbagai fenomena yang terjadi itu sangat memprihatinkan kita semua, sebab peserta didik yang seharusnya meningkatkan motivasi belajarnya salah satu diantaranya yaitu memfokuskan perhatian untuk mempelajari pengetahuan baik di lingkungan sekolah maupun di luar sekolah, namun kenyataan menunjukkan bahwa masih banyak pelajar yang kurang menyadari hal tersebut.

Implementasi pendidikan karakter membawa harapan bahwa karakter setiap peserta didik akan menjadi semakin lebih baik sekaligus memiliki keterampilan yang dapat diandalkan sesuai dengan tuntutan dari dunia usaha. Kemampuan beradaptasi di lingkungan kerja, melihat peluang kerja dan mengembangkan diri sebagai manusia yang memiliki keterampilan dan berkarakter akhlak mulia untuk dapat bekerja dalam bidang tertentu sesuai keahlian atau penguasaan kompetensi untuk bersaing di dunia usaha atau industri yang selanjutnya dapat membuatnya lebih mandiri dan produktif. Adner (dalam Muliati, 2007) mengemukakan bahwa manusia produktif adalah yang memiliki keterampilan untuk suatu tingkat tertentu dan siap dikembangkan lebih lanjut sesuai dengan ekonomi dan teknologi yang terus berkembang. 


\section{Rumusan Masalah}

Berdasarkan hal-hal yang diuraikan di atas, maka masalah penelitian ini dirumuskan sebagai berikut:

1. Bagaimanakah implementasi pendidikan karakter di SMK Negeri 1 Marioriwawo dari aspek konteks?

2. Bagaimanakah implementasi pendidikan karakter di SMK Negeri 1 Marioriwawo dari aspek input?

3. Bagaimanakah implementasi pendidikan karakter di SMK Negeri 1 Marioriwawo dari aspek proses?

4. Bagaimanakah implementasi pendidikan karakter di SMK Negeri 1 Marioriwawo dari aspek produk?

\section{TINJAUAN PUSTAKA}

\section{A. Konsep Pendidikan Karakter}

Secara sederhana pendidikan adalah proses pertumbuhan dan perkembangan manusia dengan semua potensinya melalui pengajaran (teaching) dan pembelajaran (learning) untuk mendapatkan pengetahuan (knowledge) dan atau keterampilan (skill) serta mengembangkan tingkah laku (behavior) yang baik agar bisa bermanfaat bagi kehidupan dirinya, masyarakat, dan lingkungannya (Abdul Aziz, 2011: 71).

Tafsir (2004: 6), mengemukakan bahwa "Pendidikan adalah usaha meningkatkan diri dalam segala aspeknya". Pendapat berbeda dikemukakan oleh Dobbledum (dalam Fitri, 2012: 79-80) pendidikan sering diartikan sebagai proses 
menyiapkan seorang individu menjadi kesatuan anggota masyarakat dan berperang penting dalam transfer budaya dari generasi ke generasi berikutnya, serta mengembangkan budaya itu sesuai dengan perubahan yang terjadi.

Pendidikan secara lebih terperinci dapat dikelompokkan ke dalam tiga defenisi yaitu:

a. Defenisi maha luas

Pendidikan adalah hidup. Pendidikan adalah segala pengalaman belajar yang berlangsung dalam segala lingkungan dan sepanjang hidup. Pendidikan adalah situasi hidup yang mempengaruhi pertumbuhan individu (Mudyahardjo, 2012: 3). b. Defenisi sempit

Pendidikan adalah sekolah. Pendidikan adalah segala pengaruh yang diupayakan sekolah terhadap anak dan remaja yang diserahkan kepadanya agar mempunyai kemampuan yang sempurna dan kesadaran penuh terhadap hubunganhubungan dan tugas-tugas sosial mereka (Mudyahardjo, 2012: 6).

c. Defenisi alternatif

Pendidikan adalah usaha sadar yang dilakukan oleh keluarga, masyarakat, dan pemerintah, melalui kegiatan bimbingan, pengajaran, dan/atau latihan yang berlangsung di sekolah dan di luar sekolah sepanjang hayat, untuk mempersiapkan peserta didik agar dapat memainkan peranan dalam berbagai lingkungan hidup secara tepat di masa yang akan datang (Mudyahardjo, 2012: 11); (Iskandar, 2011).

Muara dari pendidikan adalah siswa yang memiliki kekuatan spiritual keagamaan, pengendalian diri, kepribadian, kecerdasan, akhlak mulia, serta 
keterampilan yang diperlukan dirinya, masyarakat, bangsa dan negara. Artinya pendidikan menjadi sarana untuk membentuk siswa menjadi manusia yang seutuhnya, yang memiliki kecerdasan tidak hanya pada bidang intelektual, tapi juga kecerdasan emosional dan kecerdasan spiritual (Apsari, 2012: 20-21).

\section{a. Pengertian karakter}

Istilah karakter baru dipakai secara khusus dalam konteks pendidikan pada akhir abad ke-18. Pencetusnya adalah FW. Foerster. Terminologi ini mengacu pada sebuah pendekatan idealis-spiritualis dalam pendidikan, yang juga dikenal teori pendidikan formatif (Sirajuddin dalam Asmani 2011: 26).

Pengertian karakter dapat ditinjau dari dua segi, yakni segi bahasa (etimologis) dan segi istilah (terminologis). Secara etimologis Wyne dalam Musfah (2011: 127) Istilah karakter berasal dari bahasa latin character, yang berarti watak, tabiat, sifat-sifat kejiwaan, budi pekerti, kepribadian dan akhlak. Istilah karakter juga diadopsi dari bahasa latin kharakter, kharessian, dan xharaz yang berarti tool for marking, to engrave, dan pointed stake. Secara terminologis terdapat beberapa pengertian tentang karakter, sebagaimana yang telah dikemukakan oleh beberapa ahli, antara lain. Sigmund Freud (seorang ahli psikologi) dalam Sukmayadi (2012: 2), menyebutkan karakter sebagai a striving system wich underly behavior, yaitu kumpulan tata nilai yang mewujud dalam suatu sistem daya dorong (daya juang) yang melandasi pemikiran sikap dan perilaku, yang akan ditampilkan secara mantap. 
Berdasarkan beberapa pendapat yang dikemukakan sebelumnya, dapat dimaknai bahwa karakter adalah ciri khas dari diri seseorang yang diwujudkan dalam berperilaku, berfikir, bersikap, dan bertindak yang didasarkan atas kaidah moral dan norma-norma.

\section{b. Pendidikan karakter di sekolah}

Pendidikan memiliki pengaruh yang sangat besar dalam pembentukan karakter seseorang, ikut mematangkan kepribadian sehingga tingkah lakunya sesuai dengan pendidikan yang telah diterima.

Lickona (2012: 5), pendidikan karakter bukanlah merupakan ide yang baru. Sepanjang sejarah di seluruh dunia, pendidikan telah memiliki dua tujuan utama: untuk membantu para siswa menjadi pintar dan untuk membantu mereka menjadi baik. Sementara itu Elkind \& Sweet dalam Gunawan (2012: 23), mengemukakan bahwa pendidikan karakter adalah upaya yang disengaja untuk membantu memahami manusia, peduli dan inti atas nilai-nilai etis/susila. Dimana kita berpikir tentang macam-macam karakter yang kita inginkan untuk anak kita, ini jelas bahwa kita ingin mereka mampu untuk menilai apa itu kebenaran/ hak-hak, dan kemudian melakukan apa yang mereka percaya menjadi yang sebenarnya.

Senada dengan hal itu Amri, dkk., (2011: 4), mengemukakan bahwa pendidikan karakter adalah suatu sistem penanaman nilai-nilai karakter kepada warga sekolah yang meliputi komponen pengetahuan, kesadaran atau kemauan dan tindakan untuk melaksanakan nilai-nilai tersebut. Dalam pendidikan karakter di sekolah semua komponen (pemangku pendidikan) harus dilibatkan, disamping itu pendidikan 
karakter dimaknai sebagai suatu perilaku warga sekolah yang dalam menyelenggarakan pendidikan harus berkarakter. Dari beberapa pengertian karakter yang dikemukakan di atas dapat dimaknai bahwa pendidikan karakter adalah pendidikan yang menanamkan nilai-nilai karakter pada diri peserta didik dan menerapkan secara sadar nilai-nilai tersebut dalam berperilaku dan bertindak dalam kehidupan dirinya di lingkungan keluarga, masyarakat, bangsa dan negaranya.

Sebagai suatu sistem pendidikan, maka dalam pendidikan karakter juga terdiri dari unsur-unsur pendidikan yang selanjutnya akan dikelola melalui bidang-bidang perencanaan, pelaksanaan, dan pengendalian. Unsur-unsur pendidikan karakter yang akan direncanakan, dilaksanakan, dan dikendalikan tersebut antara lain meliputi. (a) nilai-nilai karakter kompetensi lulusan; (b) muatan kurikulum nilainilai karakter, (c) nilai-nilai karakter dalam pembelajaran; (d) nilai-nilai karakter pendidik dan tenaga kependidikan; dan (e) nilai-nilai karakter pembinaan kepesertadidikan (Kemendiknas, 2010a: 25).

Berdasarkan beberapa pendapat di atas dapat dimaknai bahwa pendidikan karakter di sekolah adalah serangkaian upaya yang dirancang secara sistematis untuk membantu peserta didik di lingkungan sekolah dalam memahami nilai-nilai yang berhubungan dengan Tuhan Yang Maha Esa, diri sendiri, sesama dan lingkungan serta bangsanya yang terwujud dalam satu kesatuan antara pikiran, sikap, perkataan dan perbuatan berdasarkan atas norma-norma agama, hukum, tata karma, budaya, dan adat istiadat yang berlaku. 


\section{c. Implementasi pendidikan karakter di sekolah}

Menurut Fitri (2012: 45) pendidikan karakter dapat diimplementasikan melalui beberapa strategi dan pendekatan, yang meliputi: (1) pengintegrasian nilai dan etika pada setiap mata pelajaran; (2) internalisasi nilai poisitif yang ditanamkan oleh semua warga sekolah (kepala sekolah, guru, dan orang tua); (3) pembiasaan dan latihan. Dengan komitmen dan dukungan berbagai pihak, institusi sekolah dapat mengimplementasikan kegiatan-kegiatan positif seperti salam, senyum, dan sapa (3S) setiap hari saat anak datang dan pulang sekolah; (4) pemberian contoh/teladan; (5) penciptaan suasana berkarakter di sekolah; dan (6) pembudayaan.

\section{d. Tujuan dan fungsi pendidikan karakter}

Menurut Kemendiknas (2010b), tujuan pendidikan karakter antara lain:

1) mengembangkan potensi kalbu/nurani/afektif peserta didik sebagai manusia dan warga negara yang memiliki nilai-nilai budaya dan karakter bangsa.

2) mengembangkan kebiasaan dan perilaku peserta didik yang terpuji dan sejalan dengan nilai-nilai universal dan tradisi budaya bangsa yang religius.

3) menanamkan jiwa kepemimpinan dan tanggung jawab peserta didik sebagai generasi penerus bangsa.

4) mengembangkan kemampuan peserta didik untuk menjadi manusia yang mandiri, kreatif, dan berwawasan kebangsaan. 
5) mengembangkan lingkungan kehidupan sekolah sebagai lingkungan belajar yang aman, jujur, penuh kreativitas dan persahabatan, serta dengan rasa kebangsaan yang tinggi dan penuh kekuatan (dignity). Pendidikan karakter pada dasarnya bertujuan membentuk dan membangun pola pikir, sikap, dan perilaku peserta didik agar menjadi pribadi yang positif, berakhlak karimah, berjiwa luhur, dan bertanggung jawab.

Adapun pendidikan karakter berfungsi:

1) pengembangan: pengembangan potensi peserta didik untuk menjadi perilaku yang baik bagi yang telah memiliki sikap dan perilaku yang mencerminkan budaya dan karakter bangsa peserta didik.

2) perbaikan: memperkuat kiprah pendidikan nasional untuk bertanggung jawab dalam pengembangan potensi peserta didik yang lebih bermartabat.

3) penyaring: untuk menyaring budaya-budaya bangsa sendiri dan budaya bangsa lain yang tidak sesuai dengan nilai-nilai dan karakter budaya bangsa (Kemendiknas, 2010d).

Perlunya pendidikan karakter dijelaskan oleh Lickona dalam Sukmayadi (2012: 34-35), yang mengungkapkan beberapa alasan pokok di antaranya: (1) banyaknya generasi muda saling melukai karena lemahnya kesadaran pada nilainilai moral; (2) memberikan nilai-nilai moral pada generasi muda merupakan salah satu fungsi peradaban yang paling utama; (3) peran sekolah sebagai pendidik karakter menjadi semakin penting ketika banyak anak-anak memperoleh sedikit pengajaran 
moral dari orang tua, masyarakat, atau lembaga keagamaan; (4) masih adanya nilainilai moral yang secara universal masih diterkima seperti perhatian, kepercayaan, rasa hormat, dan tanggung jawab; (5) demokrasi memiliki kebutuhan khusus untuk pendidikan moral karena demokrasi merupakan peraturan dari, untuk dan oleh masyarakat; (6) tidak ada sesuatu sebagai pendidikan bebas nilai, sekolah mengajarkan nilai-nilai setiap hari melalui desain ataupun tanpa desain; (7) komitmen pada pendidikan karakter penting manakala kita mau dan terus menjadi guru yang baik; dan (8) pendidikan karakter yang efektif membuat sekolah lebih beradab, peduli pada masyarakat, dan mengacu pada performasi akademik yang mengikat.

\section{B. Tinjauan Evaluasi}

\section{a. Pengertian evaluasi}

Terdapat beberapa defenisi tentang evaluasi yang `dikemukakan oleh pakar antara lain: Brown (dalam Sudijono, 2011: 1) secara sederhana mengemukakan bahwa evaluasi merupakan suatu tindakan atau suatu proses untuk menentukan nilai dari sesuatu. Sementara itu Stufflebeam (dalam Arikunto, 2008: 1) mengemukakan bahwa evaluasi merupakan proses penggambaran, pencarian, dan pemberian informasi yang sangat bermanfaat bagi pengambilan keputusan dalam menentukan alternatif yang tepat dalam mengambil sebuah keputusan. 


\section{b. Evaluasi program}

Menurut Arikunto (2008: 291) "Program diartikan sebagai suatu kegiatan yang direncanakan dengan saksama". Sementara itu Wirawan (2011: 17), mengemukakan bahwa "program adalah kegiatan atau aktivitas yang dirancang untuk melaksanakan kebijakan dan dilaksanakan untuk waktu yang tidak terbatas".

Adapun evaluasi program menurut para ahli antara lain: Arikunto (2008), evaluasi program yaitu suatu unit atau kesatuan kegiatan yang bertujuan mengumpulkan informasi tentang realisasi atau implementasi dari suatu kebijakan, berlangsung dalam proses yang berkesinambungan, dan terjadi dalam suatu organisasi yang melibatkan sekelompok orang guna pengambilan keputusan.

Menurut Joint Committee on Standards for Educational Evaluation (dalam Widoyoko, 2012: 9) evaluasi program merupakan evaluasi yang menilai aktivitas di bidang pendidikan dengan menyediakan data yang berkelanjutan.

Evaluasi sejak awal kemunculannya hingga sekarang terus mengalami perkembangan, dalam implementasinya ternyata evaluasi berbeda satu sama lain tergantung acuan yang digunakan oleh evaluator. Banyaknya kajian evaluasi program yang membawa implikasi semakin banyaknya model evaluasi yang berbeda cara dan penyajiannya. Namun jika ditelusuri, semua model bermuara kepada satu tujuan yang sama yaitu menyediakan informasi dalam menetapkan keputusan bagi pengambil kebijakan.

Dari beberapa model evaluasi yang ada, tulisan ini lebih fokus dan detail membahas model evaluasi CIPP. Model evaluasi CIPP mulai dikembangkan 
oleh Daniel Stufflebeam pada tahun 1965. Model CIPP berorientasi pada suatu keputusan (a decision oriented evaluation approach structured) Tujuannya adalah untuk membantu administrator (kepala sekolah dan guru) dalam membuat keputusan (Arifin, 2012: 78).

CIPP adalah singkatan Context evaluation, Input evaluation, Process evaluation, Product evaluation, yang memandang program yang dievaluasi sebagai sebuah sistem sekaligus merupakan sasaran dari evaluasi. Sesuai dengan nama modelnya, model ini membagi empat jenis kegiatan evaluasi, yaitu:

a). Evaluasi konteks (Context Evaluation). Sax (dalam Widoyoko, 2012: 181-182) mendefenisikan evaluasi konteks, sebagai berikut: ... evaluasi konteks merupakan penggambaran dan spesifikasi tentang lingkungan program, kebutuhan yang belum terpenuhi, karakteristik populasi dan sampel dari individu yang dilayani dan tujuan program. Evaluasi konteks membantu merencanakan keputusan, menentukan kebutuhan program, dan merumuskan tujuan program

b). Evaluasi input (Input Evaluation). Tahapan kedua dari CIPP adalah evaluasi input. Menurut Tayibnafis (2008: 14), evaluasi ini membantu mengatur keputusan, menentukan sumber-sumber yang ada, alternatif apa yang diambil, apa rencana dan strategi untuk mencapai kebutuhan. Komponen evaluasi masukan meliputi: (1) Sumber daya manusia; (2) Sarana dan peralatan pendukung; (3) dana atau anggaran; dan (4) berbagai prosedur dan aturan yang diperlukan. Evaluasi masukan untuk mencari jawaban atas pertanyaan: Apa yang harus dilakukan? (What should be done?) Stufflebeam (dalam Wirawan, 2011: 93). 
c). Evaluasi proses (Process Evaluation). Tahapan ketiga dari CIPP yaitu evaluasi proses. Menurut Worthen \& Sanders (1981) (dalam Widoyoko, 2012: 182), evaluasi proses menekankan pada 3 tujuan: (1) untuk mendeteksi atau memprediksi rancangan prosedur atau rancangan implementasi selama tahap implementasi; (2) menyediakan informasi

d). Evaluasi produk (Product Evaluation). Sax (dalam Widoyoko, 2012: 183) merumuskaan fungsi evaluasi bahwa dari hasil evaluasi proses diharapkan dapat membantu pimpinan proyek atau guru untuk membuat keputusan yang berkenang dengan kelanjutan, akhir maupun modifikasi program.

\section{METODE PENELITIAN}

\section{A. Jenis Penelitian}

Berdasarkan bentuk data yang akan diteliti maka penelitian ini dikategorikan sebagai penelitian evaluasi. Penelitian ini menggunakan pendekatan kualitatif dengan menggunakan metode deskriptif analisis.

Pendekatan evaluasi yang akan digunakan untuk mengevaluasi pelaksanaan pendidikan karakter di SMK Negeri 1 Marioriwawo adalah pendekatan dengan menggunakan model evaluasi C-I-P-P (Context-Input-Process-Product) yang dikembangkan oleh Daniel Stufflebean.

\section{B. Desain Penelitian}

Sebagaimana dikemukakan sebelumnya Model evaluasi CIPP dalam pelaksanaannya lebih banyak digunakan oleh para evaluator, karena model ini lebih 
komprehensif jika dibandingkan dengan model evaluasi lainnya. CIPP adalah singkatan Context evaluation, Input evaluation, Process evaluation, Product evaluation, dimana model CIPP ini adalah model evaluasi yang memandang program yang dievaluasi sebagai sebuah sistem sekaligus merupakan sasaran dari evaluasi.

\section{Teknik Analisis Data}

Penelitian ini mendeskripsikan implementasi pendidikan karakter di SMK Negeri 1 Marioriwawo. Pengolahan data dalam penelitian ini menggunakan empat tahapan, yaitu:

1) pengumpulan data

Pengumpulan data peneliti lakukan dengan mengumpulkan data yaitu mencatat semua informasi dari stakeholder (pengelola, pendidik, dan peserta didik) secara objektif dan apa adanya sesuai dengan hasil kuesioner, observasi, wawancara serta dokumentasi.

2) reduksi data

Mereduksi data berarti membuat rangkuman, memilih hal-hal pokok, memfokuskan pada hal-hal penting, mencari tema dan pola, serta membuang yang dianggap tidak perlu (Munarfah dan Hasan, 2009:168). Selama melaksanakan penelitian, maka jumlah data akan semakin banyak, rumit dan kompleks, untuk itu perlu segera dilakukan analisis data melalui reduksi data. Pilihan data yang tidak perlu akan dibuang, dan pilihan data yang perlu akan dikumpulkan lalu diverifikasi hingga dinyatakan tidak ada lagi yang dibuang. 
3) penyajian data

Langkah selanjutnya Setelah data direduksi adalah mendisplay data. Dalam penelitian kualitatif, penyajian data dapat dilakukan dalam bentuk uraian singkat, bagan, dan sejenisnya. Dalam hal ini Milles dan Humberman (dalam Sugiono, 2009:95) menyatakan yang paling sering digunakan untuk menyajikan data dalam penelitian kualitatif adalah dengan teks yang bersifat naratif.

4) kesimpulan atau verifikasi data

Proses selanjutnya setelah pengumpulan data, reduksi data dan penyajian data, adalah penarikan kesimpulan atau verifikasi data. Semua data hasil observasi, wawancara, dan angket yang terkumpul diamati secara menyeluruh dan disusun secara sistematis sehingga dapat diperoleh satu kesimpulan mengenai pelaksanaan pendidikan karakter di SMK Negeri 1 Marioriwawo. Kesimpulan hasil analisis data kemudian diverifikasi melalui peninjauan ulang hingga benar-benar dinyatakan datanya valid.

\section{Pengecekan Keabsahan Data}

Pengujian keabsahan data dalam penelitian ini menggunakan teknik triangulasi. Triangulasi adalah teknik pemeriksaan keabsahan data yang memanfaatkan sesuatu yang lain dalam membandingkan hasil wawancara terhadap objek penelitian (Moloeng, 2004:330).

Triangulasi data dari penelitian ini diperoleh dengan melakukan cross-check informasi antara informan yang satu dengan informan yang lain. 


\section{HASIL PEMBAHASAN}

Pada bab ini diuraikan mengenai hasil penelitian yang terdiri dari deskripsi hasil penelitian evaluasi implementasi pendidikan karakter di SMK Negeri 1 Marioriwawo.

\section{Hasil Penelitian}

a. Nilai-nilai karakter

Analisis data sebelumnya menunjukkan bahwa berdasarkan keseluruhan nilainilai karakter yang diimplementasikan di SMK Negeri 1 Marioriwawo dari 200 responden peserta didik nampak bahwa karakter peserta didik telah berada pada kategori mulai berkembang, hal ini ditunjukkan oleh hasil kuesioner dari 37 pernyataan, 3 orang atau 1,5 persen menjawab belum terlihat, 56 orang atau 28 persen menjawab mulai terlihat, 124 orang atau 62 persen menjawab mulai berkembang, dan 17 orang atau 8,5 persen menjawab membudaya dengan konsisten.

b. Nilai-nilai Evaluasi

Sedangkan analisis data berdasarkan keseluruhan aspek CIPP, menunjukkan bahwa nilai akumulasi aspek CIPP peserta didik berada pada kategori baik, hal ini ditunjukkan oleh hasil kuesioner dari 37 pernyataan terdapat 10 orang atau 5 persen berkategori kurang baik, 58 orang atau 29 persen cukup baik, 102 orang atau 51 persen baik, dan 30 orang atau 15 persen berada pada kategori sangat baik. 


\section{KESIMPULAN}

\section{A. Simpulan}

Berdasarkan hasil penelitian, maka dapat disimpulkan bahwa evaluasi implementasi pendidikan karakter di SMK Negeri 1 Marioriwawo berdasarkan aspek-aspek karakter yang dikembangkan tergolong berkategori mulai berkembang. Adapun implementasi pendidikan karakter ditinjau dari aspek evaluasi, maka dapat disimpulkan:

1. Implementasi pendidikan karakter di SMK Negeri 1 Marioriwawo berdasarkan aspek konteks berada pada kategori baik, dimana kebijakan yang telah ditetapkan oleh pihak sekolah telah membawa perubahan secara umum pada warga SMK Negeri 1 Marioriwawo.

2. Implementasi pendidikan karakter di SMK Negeri 1 Marioriwawo dari aspek input berada pada kategori cukup baik, dimana sarana dan prasarana yang dimiliki masih minim sehingga berimplikasi pada implementasi pendidikan karakter masih menemui hambatan.

3. Implementasi pendidikan karakter di SMK Negeri 1 Marioriwawo dari aspek proses berada pada kategori baik, hal ini ditunjukkan oleh respon peserta didik yang antusias dalam pelaksanaan pendidikan karakter.

4. Implementasi pendidikan karakter di SMK Negeri 1 Marioriwawo dari aspek produk berada pada kategori baik, hal ini ditunjukkan pada perubahan sikap siswa yang secara umum sudah mampu mengamalkan dari nilai-nilai karakter yang telah dicanangkan. 
Secara umum dari keseluruhan dimensi dan aspek yang diteliti dapat disimpulkan bahwa implementasi pendidikan karakter di SMK Negeri 1 Marioriwawo berada pada kategori baik.

\section{B. Saran}

Mengacu pada hasil penelitian yang diperoleh, maka demi pengembangan dan kemajuan pendidikan karakter peserta didik ke depan, berikut dikemukakan beberapa alternatif sebagai masukan atau saran bagi pengelola di satuan pendidikan dan pemerintah.

1. Kepada kepala sekolah SMK Negeri 1 Marioriwawo disarankan agar lebih memotivasi pendidik dan tenaga pendidikan serta warga sekolah sehingga pelaksanaan pendidikan karakter di SMK Negeri 1 marioriwawo menjadi semakin lebih baik.

2. Kepada pendidik dan tenaga kependidikan disarankan agar dapat lebih membangun kepedulian nilai-nilai karakter dengan menjadi teladan bagi peserta didik, meningkatkan pembiasaan untuk berbuat berdasarkan nilai-nilai karakter, sehingga nilai-nilai karakter peserta didik dapat menjadi spontanitas dalam berperilaku.

3. Kepada pihak pemerintah Kabupaten Soppeng agar dapat lebih mendorong pelaksanaan pendidikan karakter pada satuan pendidikan. 


\section{Rekomendasi}

Berdasarkan hasil evaluasi terhadap implementasi pendidikan karakter di SMK Negeri 1 Marioriwawo, maka peneliti merekomendasikan beberapa hal sebagai berikut.

1. Kepada pendidik di SMK Negeri 1 Marioriwawo agar mempunyai instrumen evaluasi untuk dapat mengukur pencapaian nilai-nilai karakter peserta didik di sekolah.

2. Kepada kepala sekolah SMK Negeri 1 Marioriwawo agar dapat mendayagunakan seluruh potensi yang ada sehinga implementasi pendidikan karakter dapat tercapai dengan efektif, dan efisien.

3. Kepada pihak pemerintah Kabupaten Soppeng agar dapat membentuk tim monitoring dan evaluasi terhadap implentasi pendidikan karakter pada satuan pendidikan.

\section{DAFTAR PUSTAKA}

Abdul Aziz, Hamka. 2011. Pendidikan Karakter Berpusat Pada Hati. Jakarta: Al Mawardi Prima.

Amri, Sofan. 2011. Implementasi Pendidikan Karakter Dalam Pembelajaran "Strategi Analisis Dan Pengembangan Karakter Siswa Dalam Proses Pembelajaran". Jakarta: Prestasi Pustaka.

Apsari, Yulie. 2012. Implementasi Standar Proses dalam Meningkatkan Mutu Pembelajaran (Studi Kasus Pada SMP Negeri 19 Jakarta) Tesis. Jakarta: Program Pascasarjana UPI Jakarta, (online), (http://www.repository.upi.edu,/tesisview.php? no tes, Diakses 22 Desember 2012). 
Arifin, Zainal. 2012. Evaluasi Pembelajaran Prinsip, Teknik, Prosedur. Bandung: PT. Remaja Rosdakarya.

Arikunto, Suharsimi. 2008. Dasar-Dasar Evaluasi Pendidikan. Jakarta: Bumi Aksara.

Asmani, Jamal Ma'mur. 2011. Buku Panduan Internalisasi Pendidikan Karakter di Sekolah. Yogyakarta: DIVA Press.

Fitri, Agus Zaenul. 2012. Reinventing Human Character: Pendidikan Karakter berbasis Nilai \& Etika di Sekolah. Yogyakarta: Ar-Ruzz Media.

Gunawan, Heri. 2012. Pendidikan Karakter konsep dan Implementasi. Bandung: Alfabeta.

Iskandar, Akbar. 2011. Dick \& Carey, ADDIE, ASSURE, dan PROGRAM. Di akses pada tanggal 12 Januari 2013

Iskandar, Akbar. 2013. Pengembangan Perangkat Penilaian Psikomotor Di Sekolah Menengah Kejuruan. Jurnal Inspiration, 3(1), 37-46.

Kemendiknas. 2010a. Panduan Pendidikan Karakter di Sekolah Menengah Pertama. Pusat Kurikulum Balitbang. Jakarta. . 2010b. Pengembangan Pendidikan Budaya dan Karakter Bangsa. Puskurbuk. Jakarta.

Lickona, Thomas. 2012. Character Matters: Persoalan Karakter bagaimana membantu anak mengembangkan penilaian yang baik, integritas, dan kebajikan penting lainnya. Jakarta: Bumi Aksara.

Moleong, Lexy J. 2004. Metodologi Penelitian Kualitatif. Bandung: PT Remaja Rosdakarya.

Mudyaharjo, Redja. 2012. Pengantar Pendidikan Sebuah Studi Awal tentang DasarDasar Pendidikan pada Umunya dan Pendidikan di Indonesia. Jakarta: PT. Rajagrafindo Persada.

Muliati, A. 2007. Evaluasi Program Pendidikan Sistem Ganda: Suatu Penelitian Evaluatif berdasarkan Stake's Countenance Model Mengenai Program Pendidikan Sistem Ganda Pada Sebuah SMK di Sulawesi Selatan (2005/2007).

(online), (http://www.damandiri.or.id/file/muliatiyunjabab.pdf.windows) Internet Explorer, Diakses 18 Oktober 2012. 
Munarfah, Andi dan Muhammad Hasan. 2009. Metode Penelitian. Jakarta: Praktika Aksara Semesta.

Musfah. 2011. Pemikiran Pendidikan: Upaya Membangun Manusia berkarakter Melalui Pendidikan holistik. Jakarta: Prenada Media.

Patoni. 2012. Penguatan Karakter Melalui Kegiatan Ekstrakurikuler Untuk Memantapkan Sikap Nasionalisme Siswa (Studi Kasus di SMKN 2 Purwakarta). Tesis. Jakarta: Program Pascasarjana UPI Jakarta, (online), (http://www.repository.upi.edu,/tesisview.php? no tes, Diakses 2 Desember 2012).

Sudijono. Anas. 2011. Pengantar Evaluasi Pendidikan. Jakarta: RajaGrafindo Persada.

Sugiyono. 2009. Metode Penelitian Administrasi. Bandung: Alfabeta

Sukmayadi, Trisna. 2012. Pengembangan Pendidikan Karakter Berbasis Nilai-Nilai Kearifan lokal Sunda: Studi Kasus di SMA Negeri 2 Cimahi. Tesis. Jakarta: Program Pascasarjana UPI Jakarta, (online), (http://www.repository.upi.edu,/tesisview.php? no tes, Diakses 2 Desember 2012).

Tafsir, Ahmad. 2004. Ilmu Pendidikan dalam Perspektif Islam. Bandung: Remaja Rosda Karya.

Tayibnapis, Farida Yusuf. 2008. Evaluasi program dan Instrumen Evaluasi Untuk program Pendidikan dan penelitian. Jakarta: Rineka Cipta.

Widoyoko, S. Eko Putro. 2012. Evaluasi Program Pembelajaran, panduan praktis bagi pendidik dan calon pendidik. Yogyakarta: Pustaka Pelajar.

Wirawan. 2011. Evaluasi: Teori, Model, Standar, Aplikasi, dan Profesi. Jakarta: Rajawali Pers. 